\title{
Antioxidant Capacity and Chemical Characterization of Açaí (Euterpe oleracea Mart.) Fruit Fractions
}

\author{
Daniela Souza Ferreira ${ }^{1, *}$, Alex Linardi Gomes ${ }^{2}$, Marta Gomes da Silva ${ }^{2}$, Adriana Barreto Alves ${ }^{2}$, \\ Wellington Hortenci Dall Agnol ${ }^{3}$, Roseli Aparecida Ferrari ${ }^{2}$, Paulo Roberto Nogueira Carvalho ${ }^{2}$, \\ Maria Teresa Bertoldo Pacheco ${ }^{2}$ \\ ${ }^{1}$ School of Food Engineering, University of Campinas, Brazil \\ ${ }^{2}$ Food Chemistry and Applied Nutrition Center, Institute of Food Technology [ITAL], Brazil \\ ${ }^{3}$ Acai Industry and Trade Ltd. (ACAIMAZON), Brazil
}

Copyright $\mathrm{O} 2016$ by authors, all rights reserved. Authors agree that this article remains permanently open access under the terms of the Creative Commons Attribution License 4.0 International License

\begin{abstract}
Açaí (Euterpe oleracea) has a high nutritional value because of its antioxidant compounds, which have the appeal of health benefits. This fruit is native of the floodplain of the Brazilian state of Pará, and was fractionated in peel, pulp, peel plus pulp, and seed. The aim of this research was to evaluate the nutritional composition, total phenolic content, total anthocyanins, antioxidant capacity and the fatty acid profile of these fractions. The highest lipid content (33.5 g. $\left.100 \mathrm{~g}^{-1} \mathrm{DB}\right)$ was present in the açaí pulp fraction and gas chromatography analysis showed unsaturated fatty acids (71.8\%). The peel and seed fractions had the highest dietary fiber content ( 86.1 and 83.4 g. $100 \mathrm{~g}^{-1}$ DB, respectively), being insoluble dietary fiber predominant in the peel. The peel has the highest total anthocyanins $\left(372.8 \mathrm{mg} .100 \mathrm{~g}^{-1} \mathrm{DB}\right)$ and the seed has the highest total phenolic content (3602 mg. $\left.100 \mathrm{~g}^{-1} \mathrm{DB}\right)$ and the highest antioxidant capacity $(88.5$ $\mu \mathrm{mol} \mathrm{TE} / \mathrm{g} \mathrm{DB})$. The marketing approach in the industry of açaí products is aimed at its antioxidant and energy potential, considering the high content of lipids and carbohydrates, showing that $100 \mathrm{~g}$ of fresh fruit has approximately $130 \mathrm{cal}$. These results show promising perspectives for the use of açaí fractions for new tropical products with considerable levels of nutrients and antioxidant capacity.
\end{abstract}

Keywords Euterpe oleracea, Nutritional Composition, Fractionation, GC-FID

\section{Introduction}

Açaí (Euterpe oleracea Mart.) is an economically significant fruit originated from the Brazilian Amazon. The açaí fruit is commonly found in Central and South American countries such as Peru, Ecuador, Colombia and Brazil, but the biggest producer is Brazil. The state of Pará harvested more than 200,000 tonnes in 2013; it has been the state responsible for $55 \%$ of the Brazilian production and it exported approximately 7,000 tonnes in 2012 to USA, Japan and South Korea [1].

The fruits, which grow in bunches, are small, approximately 1 to $1.5 \mathrm{~cm}$ in diameter, and their color range from red to black. The exocarp is a deep purple colored peel that covers the mesocarp, and it has a thickness of only 1 to 2 $\mathrm{mm}$; the seed represents approximately $85 \%$ of the volume of the fruit [2,3], however, only $15 \%$ of the fruit are used as food (peel plus pulp).

Interest in the research and development of açaí has increased mainly because of its nutritional value and antioxidant capacity because of its high levels of flavonoids, especially anthocyanin, which provide its excellent potential as a functional food ingredient. This dark purple fruit has been export mainly to the USA and Europe to be used generally in fruit juices and dietary supplements, associating health-related benefits [4-6]. Previous study has demonstrated an increase in plasma antioxidant capacity induced by the consumption of the açaí pulp [7]. Souza et al. [8] suggest that the consumption of açaí improves the antioxidant status and has a hypocholesterolemic effect in an animal model of dietary-induced hypercholesterolemia. Moreover, açaí offers a rich source of bioactive polyphenols and Del Pozo-Insfran et al. [9] confirmed its effects on the anti-proliferation and apoptosis of leukemia HL-60 cells.

The fruit is highly perishable; therefore, it is better utilized in processed products, such as fruit juices, smoothies and viscous pulp. It is noticed a slight hint of bitter aftertaste, which resembles that of chocolate, in açaí products. Consumers prefer juices with a low açaí content (4 to $5 \%$ of açaí), but when health benefits are perceived they accept this taste dissatisfaction [10]. Probably, the taste is related to compounds present in fruit that are incorporated during the processing.

It is known that the daily consumption of these fruits can contribute to improve the antioxidant serum. On other hand, 
the knowledge of the distribution of the bioactive compounds present in seed, pulp and peel of these fruits could contribute to a competitive agribusiness. Because of this, the characterization of the exocarp and mesocarp of the açaí is very important for possible commercial applications [11]. However, most of the açaí fruit studies are addressed to the edible part of the fruit (peel plus pulp - mesocarp), added of water and, in many cases, bought in markets without information about the origin. Thus, the aim of this work was to carry out a detailed study of açaí fractions: pulp plus peel, peel, pulp and seed, and compare the chemical composition and the antioxidant capacity between the fractions. This study will allow the development of new technologies for its fractional consumption. The differences in composition between fractions may promote different applications, processing and commercialization.

\section{Materials and Methods}

\subsection{Plant Material}

Açaí fruits (Euterpe oleracea Mart.), $100 \mathrm{~kg}$, were collected in the floodplain of the Guamá river, in the region of Castanhal (state of Pará, Brazil). They are palm trees natives to the forest management (Location $1^{\circ} 29^{\prime} 04.98^{\prime \prime} \mathrm{S}$, $47^{\circ} 59^{\prime} 27.46^{\prime \prime} \mathrm{W}-15 \mathrm{~m}$ ). The fruits were packed in plastic bags of approximately $2 \mathrm{~kg}$ and stored in a freezer at $-10 \pm$ $5^{\circ} \mathrm{C}$ until testing.

\subsection{Sample Preparation}

The samples analyzed were: 1) whole fruit, 2) pulp plus peel, 3) peel, 4) pulp and 5) seed fractions. Figure 1 shows some açaí fractions. The whole fruit was crushed in a grinding mill (A-20, Catel, Brazil) and this sample was called "fruit". Another sample of the whole fruit was ground using a sieve until revealing the seed, and this sample was called "pulp plus peel".

The peel, pulp and seed fractions were obtained using an abrasive system. Water was added to facilitate the separation of the "peel" and "pulp" fractions. The peels were removed and the material remaining from the peeling (pulp plus seed) was immersed in distilled water $\left(40-50^{\circ} \mathrm{C}\right)$ for 1 hour to facilitate the separation of the pulp from the seed. The separation of pulp and seed was performed using a vertical cylinder containing horizontal turning rods. Residual fibers were observed in the pulp fraction after pulping, unlike the traditional methods of pulping in which these fibers are removed. The fractions were weighted in triplicate, and the mean yield of each fraction and total solids were determined. The samples were stored at $4{ }^{\circ} \mathrm{C}$ until analysis, accomplished in one day.

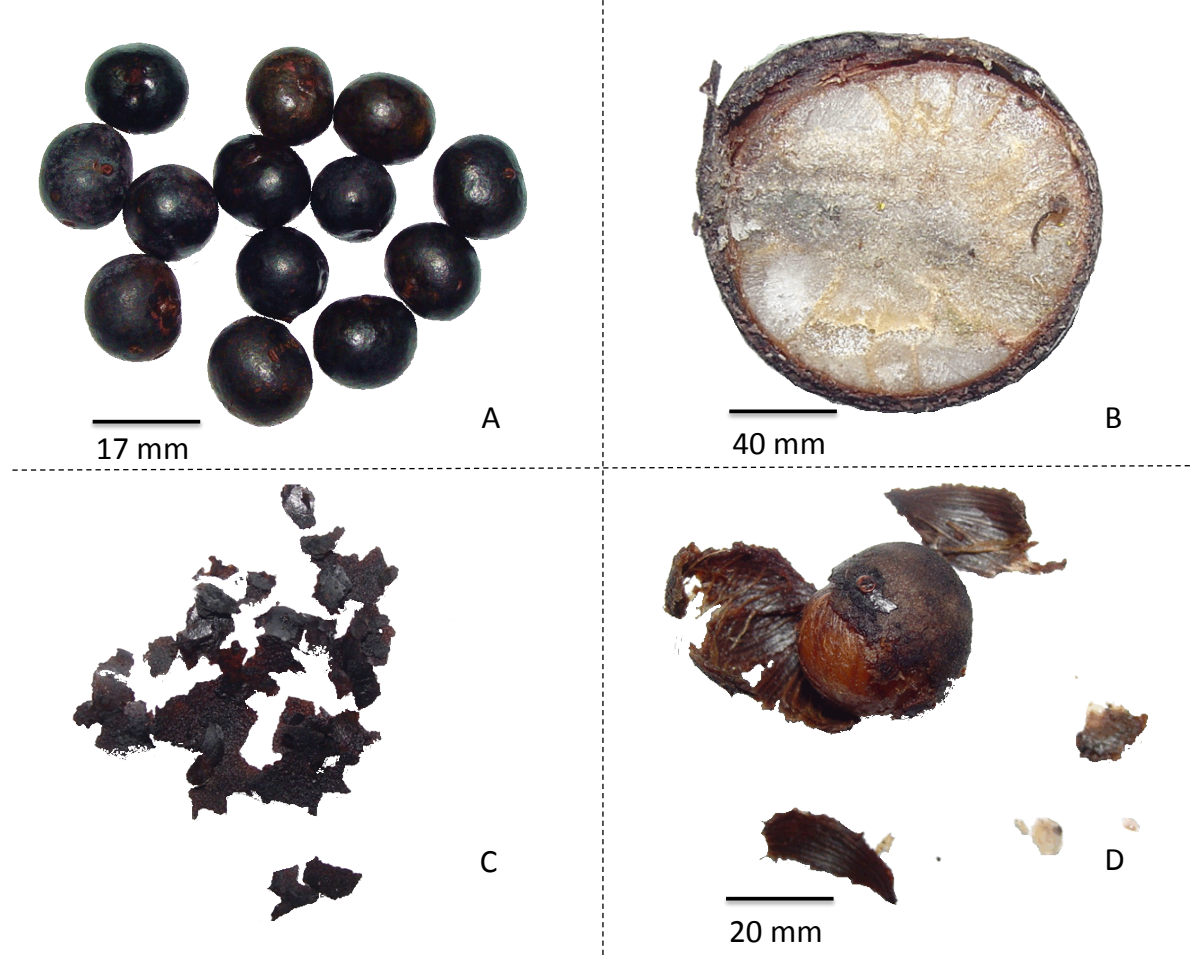

Figure 1. Açaí fractions: (A) Whole fruit, (B) Fruit in transversal section, (C) Peel and (D) Pulp with fibers in the seed. 


\subsection{Reagents}

The HPLC grade Methanol and Ethanol, 6-hydroxy-2,5,7,8-tetramethylchroman-2-carboxylic acid (Trolox), ABTS (2,2-azino-di-(3-ethylbenzothialozine sulphonic acid) were obtained from Sigma Chemical Co. (St. Louis, USA). The Folin-Ciocalteu reagents were obtained from Dinamica Química Contemporânea Ltda (Diadema, Brazil). All other chemical reagents and solvents used were of analytical grade (Sigma-Aldrich, St. Louis, USA).

\subsection{Nutritional Composition}

Moisture, ash and protein content were determined using the 920.151, 940.26 and 920.152 reference methods, respectively, described by the AOAC [12]. The total carbohydrate content was calculated with the formula: $\%$ of carbohydrate $=100-\%$ of moisture $-\%$ of lipid $-\%$ of protein - $\%$ of ash. All the analyses were performed in triplicate. Total dietary fiber (DF), soluble (SDF) and insoluble dietary fiber (IDF) were determined, in quadruplicate, using the enzymatic-gravimetric method (991.43, AOAC).

\subsection{Fatty Acid Profile}

The lipid content was determined using the Bligh Dyer [13] method. The lipids present in the pulp and seed were subjected to esterification of fatty acids according to the method described by Hartman and Lago [14]. The analyzes were performed on a gas chromatograph, model 3900 (Varian, Palo Alto, CA, USA), equipped with split injection port, CP-Sil 88 capillary column $(100 \mathrm{~m} \times 0.25 \mathrm{~mm}$ id, $0.2-\mu \mathrm{m}$ film thickness), oven with temperature programming ramp and flame ionization detector (FID). The injections were performed using hydrogen as carrier gas at constant pressure of $13.5 \mathrm{psi}$. The initial temperature of the oven was $140^{\circ} \mathrm{C}$ for $2 \mathrm{~min}$, then programmed to increase from $140^{\circ} \mathrm{C}$ to $235^{\circ} \mathrm{C}$ (rate of $2.5^{\circ} \mathrm{C} / \mathrm{min}$ ) and posteriorly kept at $235^{\circ} \mathrm{C}$ for 10 minutes. The esters were identified by comparison of retention times with standards (Supelco 37 Comp. FAME Mix) and the quantification was performed by area percentage. The results were expressed as $\mathrm{g} / 100 \mathrm{~g}$ of total fatty acids.

\subsection{Phenolic Compounds and Anthocyanin Extraction}

A solution of $95 \%$ ethanol/1.5 N HCl $(85: 15$, v/v) was used to extract the phenolic compounds and anthocyanins from the açaí fruit fractions. The samples were placed into the solution at $4^{\circ} \mathrm{C}$ in the absence of light for 24 hours. Posteriorly, the phenolic compounds were exhaustively extracted with the solution (ethanol/ $\mathrm{HCl}$ ) and then filtered. The fractions extract were used for the determination of total phenolic content, total anthocyanins and antioxidant capacity. The extractions were performed in triplicate.

\subsubsection{Total Phenolic Content}

The determination of the total phenolic content (TP) was performed according to the Singleton and Rossi [15] method. The absorbance was measured at $750 \mathrm{~nm}$. The control was made with water, and gallic acid was used as standard. The results were expressed as $\mathrm{mg}$ gallic acid equivalent (GAE)/100g of sample.

\subsubsection{Total Anthocyanins}

The determination of total anthocyanins (TA) was performed using the procedure described by Francis [16]. The measurement of the absorbance was performed at 535 $\mathrm{nm}$ against extraction solution blanks. For the calculation of the anthocyanin content, the value of absorption coefficient $\left(E_{1 \mathrm{~cm}, 535 \mathrm{~nm}}^{1 \%}\right.$ ) of 98.2 was used, corresponding to cyanidin 3-glucoside in ethanol/1.5 N HCl [17, 18]. The results were expressed as $\mathrm{mg}$ cyanidin 3 -glucoside equivalent/100g of sample.

\subsubsection{Antioxidant Capacity}

The determination of the antioxidant capacity of the açaí fraction was performed following the procedures of Re et al. [19]. The absorbance readings were recorded at $750 \mathrm{~nm}$. The percentage of inhibition of $\mathrm{ABTS}^{-+}$was plotted against the concentration of the test sample and known solutions of Trolox. The radical scavenging activity of the test samples was expressed as $\mu$ mol of Trolox (TE)/ g of sample calculated by the ratio between the gradients of test samples and the Trolox curves.

The TP, TA and antioxidant capacity were performed using a Hitachi U2000 UV-Visible spectrophotometer (HITACHI, Tokyo, Japan).

\section{Results and Discussion}

\subsection{Açaí Fruit Fractionation}

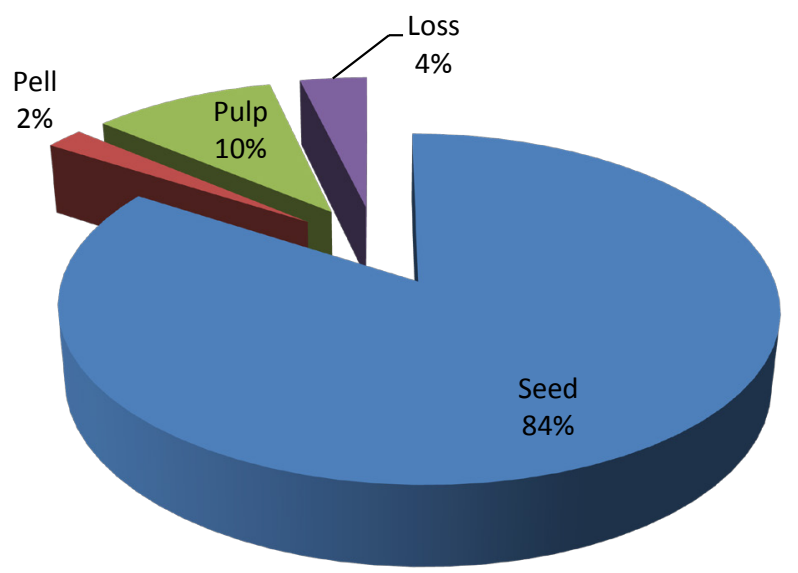

Figure 2. Mean yield of solids of açaí fractions.

Figure 2 shows the mean yield of solids of açai fractions. With $100 \mathrm{~g}$ of fresh açaí fruit, it was possible to separate the solids with mean values of $1.22 \pm 0.04 \mathrm{~g}$ of peel, $5.62 \pm 0.54$ $\mathrm{g}$ of pulp and $48.95 \pm 1.01 \mathrm{~g}$ of seed.

Previous study performed by Pessoa et al. [11] obtained 
approximately $18.8 \%$ of pulp, which corresponds to the epiderm and part of the internal parenchyma, $80.9 \%$ of core, which is the seed and part of the internal parenchyma, and $5.3 \%$ of fiber layer, all in a dry weight basis. Comparing with our results of the fractionation of açaí fruit, we had lower pulp content $(\sim 9.6 \%)$ and similar seed content $(\sim 84 \%)$.

\subsection{Chemical Composition}

Table 1 shows the chemical composition (moisture, ash, protein, lipid, carbohydrate and fiber contents) of each fraction of açaí on dry (DB) and wet (WB) weight basis. The pulp plus peel fraction presented moisture content of $37.17 \pm$ 0.20 g. $100 \mathrm{~g}^{-1}$; similar value was presented by Borges et al. [20], who found moisture content varying from 34.95 g. $100 \mathrm{~g}^{-1}$ to 42.47 g. $100 \mathrm{~g}^{-1}$ for jussara fruit (E. edulis) from the state of Santa Catarina. Others fractions presented high values of moisture, because water was added to help the separation, and the peel contains $85.38 \pm 0.10 \mathrm{~g} .100 \mathrm{~g}^{-1}$, the pulp $94.51 \pm 0.37 \mathrm{~g} .100 \mathrm{~g}^{-1}$ and the seed $38.57 \pm 0.07$ g. $100 \mathrm{~g}^{-1}$.

The concentration of protein in the pulp and peel fraction was $8.44 \pm 0.20 \mathrm{~g} .100 \mathrm{~g}^{-1} \mathrm{DB}$ (Table 1); this value is consistent with previously reported content for jussara and açaí fruit $\left(8.21 \mathrm{~g} .100 \mathrm{~g}^{-1}\right.$ to $\left.10.2 \mathrm{~g} .100 \mathrm{~g}^{-1} \mathrm{DB}\right)[20,21]$. The same interpretation is acceptable for ash content, as the value found in this study was $2.61 \pm 0.00 \mathrm{~g} .100 \mathrm{~g}^{-1} \mathrm{DB}$ for pulp and peel $\left(2.2 \mathrm{~g} .100 \mathrm{~g}^{-1}\right.$ to $\left.3.2 \mathrm{~g} .100 \mathrm{~g}^{-1} \mathrm{DB}\right)[21,22]$. There is no difference in the protein and ash contents between the açaí fractions.

Dietary Fiber (DF) seems to be predominant in the carbohydrate concentration of açaí, because it represents more than $88 \%$ of the nutrients. The pulp plus peel fraction shows DF content of approximately $67.15 \mathrm{~g} .100 \mathrm{~g}^{-1} \mathrm{DB}$, but only a small portion is SDF, $0.73 \pm 0.02 \mathrm{~g} .100 \mathrm{~g}^{-1} \mathrm{DB}$. This DF content is two to three times higher than that reported by Neida and Elba [22] for açaí from Venezuela $\left(20 \mathrm{~g} \cdot 100 \mathrm{~g}^{-1}\right.$ to
30.9 g. $\left.100 \mathrm{~g}^{-1} \mathrm{DB}\right)$. The greatest concentration of DF is in the peel fraction $\left(\sim 86.05 \mathrm{~g} .100 \mathrm{~g}^{-1} \mathrm{DB}\right)$, in which just $0.65 \pm 0.05$ g. $100 \mathrm{~g}^{-1}$ are SDF (Table 1). High concentrations of DF were also found in the pulp and seed fractions (68.50 and 83.38 g. $100 \mathrm{~g}^{-1} \mathrm{DB}$, respectively). This concentration present in the seed represents approximately $92 \%$ of its composition.

The açaí pulp studied by Rufino et al. [23] has high content of DF (71.22 $\left.\pm 1.22 \mathrm{~g} .100 \mathrm{~g}^{-1} \mathrm{DB}\right)$ as well. However, the authors found a higher soluble fiber content than our study and similar insoluble content $\left(2.7\right.$ and $68.5 \mathrm{~g} .100 \mathrm{~g}^{-1}$ $\mathrm{DB}$, respectively).

After the fractionation of the açaí fruit, most parts of the fibers remained in the pulp fraction, presenting approximately $60 \%$ of DF of the edible part of the açaí fruit. The peel fraction recovered only $16 \%$ of these fibers. This fractionation is different from the traditional process to obtain açaí pulp, without the separation of IDF, because the pulp obtained does not go through the filtration process. The results of the lipid content showed that the whole fruit has the concentration of $7.34 \pm 0.19 \mathrm{~g} .100 \mathrm{~g}^{-1} \mathrm{DB}$ (Table 1). The pulp plus peel sample has lipid concentration of $12.83 \pm 0.30$ g. $100 \mathrm{~g}^{-1} \mathrm{DB}$. This value is lower than those reported in the literature for similar samples: $20.82 \pm 1.60 \mathrm{~g} .100 \mathrm{~g}^{-1}$ for Rufino et al. [23] and approximately $46.5 \mathrm{~g} .100 \mathrm{~g}^{-1}$ for Tonon et al. [21]. This low result observed in the present study can be explained by the different origin and accessions of the açaí fruit. The higher concentration of lipid is in the pulp fraction (33.49 $\pm 0.68 \mathrm{~g} .100 \mathrm{~g}^{-1} \mathrm{DB}-$ Table 1$)$. The most predominant fatty acids found in the açaí pulp were oleic, palmitic, follow by linoleic $\left(54.3 \mathrm{~g} .100 \mathrm{~g}^{-1}, 22.7 \mathrm{~g} .100 \mathrm{~g}^{-1}\right.$ and 10.9 g. $100 \mathrm{~g}^{-1} \mathrm{DB}$, respectively) (Table 2). The fatty acid profile of açaí resembles those reported by Neida and Elba [22] and also for jussara reported by Borges et al. [20]. This distribution of saturated, monounsaturated and polyunsaturated fatty acids is the same in previous work with açaí pulp [23].

Table 1. Proximate composition $\left(\mathrm{g} \cdot 100 \mathrm{~g}^{-1}\right)$ of açaí fruit fractions

\begin{tabular}{|c|c|c|c|c|c|c|c|c|c|c|}
\hline \multirow{2}{*}{ Analysis } & \multicolumn{2}{|c|}{ Whole fruit ${ }^{1}$} & \multicolumn{2}{|c|}{ Pulp plus Peel } & \multicolumn{2}{|c|}{ Peel } & \multicolumn{2}{|c|}{ Pulp } & \multicolumn{2}{|c|}{ Seed } \\
\hline & $\mathrm{WB}^{2}$ & $\mathrm{DB}^{3}$ & WB & DB & WB & DB & WB & DB & WB & DB \\
\hline Moisture & $\begin{array}{l}41.53 \pm \\
0.05\end{array}$ & & $\begin{array}{c}37.17 \pm \\
0.20\end{array}$ & & $\begin{array}{c}85.38 \pm \\
0.10\end{array}$ & & $\begin{array}{c}94,51 \pm \\
0,37\end{array}$ & & $\begin{array}{c}38,57 \pm \\
0,07\end{array}$ & \\
\hline Ash & $\begin{array}{c}0.98 \pm \\
0.00\end{array}$ & $\begin{array}{c}1.68 \pm \\
0.00\end{array}$ & $\begin{array}{c}1.64 \pm \\
0.00\end{array}$ & $\begin{array}{c}2.61 \pm \\
0.00\end{array}$ & $\begin{array}{c}0.18 \pm \\
0.01\end{array}$ & $\begin{array}{l}1.26 \pm \\
0.03\end{array}$ & $\begin{array}{c}0.21 \pm \\
0.00\end{array}$ & $\begin{array}{c}3.78 \pm \\
0.06\end{array}$ & $\begin{array}{c}0.89 \pm \\
0.01\end{array}$ & $\begin{array}{c}1.44 \pm \\
0.01\end{array}$ \\
\hline Protein & $\begin{array}{c}3.03 \pm \\
0.10\end{array}$ & $\begin{array}{c}5.18 \pm \\
0.17\end{array}$ & $\begin{array}{c}5.30 \pm \\
0.13\end{array}$ & $\begin{array}{c}8.44 \pm \\
0.20\end{array}$ & $\begin{array}{c}1.17 \pm \\
0.03\end{array}$ & $\begin{array}{c}8.01 \pm \\
0.24\end{array}$ & $\begin{array}{c}0.37 \pm \\
0.00\end{array}$ & $\begin{array}{c}6.75 \pm \\
0.06\end{array}$ & $\begin{array}{c}3.95 \pm \\
0.03\end{array}$ & $\begin{array}{c}6.42 \pm \\
0.04\end{array}$ \\
\hline Lipid & $\begin{array}{c}4.29 \pm \\
0.11\end{array}$ & $\begin{array}{c}7.34 \pm \\
0.19\end{array}$ & $\begin{array}{c}8.06 \pm \\
0.19\end{array}$ & $\begin{array}{c}12.83 \pm \\
0.30\end{array}$ & $\begin{array}{c}1.13 \pm \\
0.11\end{array}$ & $\begin{array}{c}7.70 \pm \\
0.73\end{array}$ & $\begin{array}{c}1.84 \pm \\
0.00\end{array}$ & $\begin{array}{c}33.49 \pm \\
0.68\end{array}$ & $\begin{array}{c}1.04 \pm \\
0.03\end{array}$ & $\begin{array}{c}1.70 \pm \\
0.05\end{array}$ \\
\hline Carbohydrate $^{4}$ & 50.17 & 85.80 & 47.83 & 76.13 & 12.14 & 83.02 & 3.10 & 56.43 & 55.55 & 90.43 \\
\hline $\begin{array}{l}\text { Soluble dietary } \\
\text { fiber } \\
\text { Insoluble dietary } \\
\text { fiber }\end{array}$ & & & $\begin{array}{c}0.46 \pm \\
0.02 \\
41.73 \pm \\
0.00\end{array}$ & $\begin{array}{c}0.73 \pm \\
0.02 \\
66.42 \pm \\
0.00\end{array}$ & $\begin{array}{c}0.09 \pm \\
0.01 \\
12.49 \pm \\
0.01\end{array}$ & $\begin{array}{c}0.65 \pm \\
0.05 \\
85.43 \pm \\
0.10\end{array}$ & & & & \\
\hline Dietary fiber ${ }^{5}$ & & & 42.19 & 67.15 & 12.58 & 86.05 & $3.76^{6}$ & $68.50^{6}$ & $\begin{array}{c}51.22 \pm \\
0.10\end{array}$ & $\begin{array}{c}83.38 \pm \\
0.16\end{array}$ \\
\hline
\end{tabular}

Values expressed as mean content $\left[\mathrm{g} .100 \mathrm{~g}^{-1}\right] \pm$ standard error.

${ }^{1}$ Whole fruit with seed; ${ }^{2} \mathrm{WB}=$ Wet weight basis; ${ }^{3} \mathrm{DB}=$ Dry weight basis; ${ }^{4}$ Carbohydrates calculated by difference $[100-(\mathrm{moisture}+\mathrm{ash}+$ protein + lipid)]; ${ }^{5}$ Calculated by addition (Soluble dietary fiber + Insoluble dietary fiber), except the seed, whose value of dietary fiber was obtained in laboratory; ${ }^{6}$ Calculated by difference between "pulp plus peel" and "peel" considering the percentage of each fraction obtained through this study. 
Table 2. Fatty acid composition and oil of açaí pulp

\begin{tabular}{ccc}
\hline Fatty acids & $\left(\mathrm{g} .100 \mathrm{~g}^{-1} \mathrm{DB}\right)$ & Oil (\%) \\
\hline Saturated & 8.01 & 23.9 \\
C16:0 (Palmitic acid) & 7.64 & 22.7 \\
C18:0 (Stearic acid) & 0.36 & 1.1 \\
Monounsaturated & 20.02 & 59.8 \\
C18:1 Omega-9 (Oleic acid) & 18.20 & 54.3 \\
C16:1 Omega-7 (Palmitoleic acid) & 1.82 & 5.4 \\
Polyunsaturated & 4.00 & 11.9 \\
C18:2 Omega-6 (Linoleic acid) & 3.64 & 10.8 \\
C18:3 Omega-3 (Alpha-linolenic & 0.36 & 1.1 \\
acid) & 1.3 & 3.9 \\
Others &
\end{tabular}

DB: Dry weight basis

However, the major components found in the seed oil were the oleic and myristic acids $\left(25.9\right.$ g. $100 \mathrm{~g}^{-1}$ and 22.9 g. $100 \mathrm{~g}^{-1}$, respectively) (Table 3). These results indicate that the pulp has a higher concentration of unsaturated fatty acids than the seed and this composition differs principally by the increased concentration of the myristic acid present in the seed oil.

Table 3. Fatty acid composition and oil of açaí seed

\begin{tabular}{|c|c|c|}
\hline Fatty acids & (g. $\left.100 \mathrm{~g}^{-1} \mathrm{DB}\right)$ & Oil (\%) \\
\hline Saturated & 0.85 & 50.0 \\
\hline C12:0 (Capric acid) & 0.16 & 9.4 \\
\hline C14:0 (Myristic acid) & 0.39 & 22.9 \\
\hline C16:0 (Palmitic acid) & 0.28 & 16.5 \\
\hline C18:0 (Stearic acid) & 0.02 & 1.2 \\
\hline Monounsaturated & 0.46 & 27.1 \\
\hline C18:1 Omega-9 (Oleic acid) & 0.44 & 25.9 \\
\hline $\begin{array}{c}\text { C16:1 Omega-7 (Palmitoleic } \\
\text { acid) }\end{array}$ & 0.02 & 1.2 \\
\hline Polyunsaturated & 0.31 & 18.3 \\
\hline $\begin{array}{c}\text { C18:2 Omega-6 (Linoleic } \\
\text { acid) }\end{array}$ & 0.29 & 17.1 \\
\hline $\begin{array}{c}\text { C18:3 Omega-3 } \\
\text { (Alpha-linolenic acid) }\end{array}$ & 0.02 & 1.2 \\
\hline Others & 0.08 & 4.7 \\
\hline
\end{tabular}

DB: Dry weight basis

Table 4 shows the total phenolic content (TP) expressed as gallic acid equivalent. Inside the phenolic group, the total anthocyanin (TA) content was determined based on cyanidin 3 -glucoside, which is one of the predominant anthocyanins in açaí [24].

The higher concentration of anthocyanin is in the peel fraction $\left(372.81 \pm 7.36 \mathrm{mg} .100 \mathrm{~g}^{-1} \mathrm{DB}\right)$. The pulp fraction also showed significant concentration of anthocyanins $\left(202.15 \pm 51.84 \mathrm{mg} \cdot 100 \mathrm{~g}^{-1} \mathrm{DB}\right)$, probably because of the contribution from the TA content of the residue of the peel retained in the pulp fraction, since the anthocyanins are hydrosoluble.

Dias et al. [25] found the range of 48.8 to $58.3 \mathrm{mg}$ of anthocyanins per $100 \mathrm{~g}$ of fruit (WB), which demonstrates the great variability of the anthocyanin content in E. oleracea in different maturity stages. The TA content found in the present study was $47.73 \pm 7.54 \mathrm{mg} .100 \mathrm{~g}^{-1}$ of açaí fruit (WB), and this value is close to the value reported by the authors mentioned.

The value of TA found for pulp plus peel in this study was $120.19 \pm 1.07 \mathrm{mg} .100 \mathrm{~g}^{-1} \mathrm{WB}$, and this value is inside the range reported by many authors (59.8 to $289.1 \mathrm{mg}$ of anthocyanin per $100 \mathrm{~g}$ of pulp WB) $[3,26]$.

Açaí fruit has additional compounds other than anthocyanin that contribute to the scavenging activity of free radicals, which improve its potential as functional food. This study shows that the TP content is well distributed between the peel, pulp and whole fruit fractions, but the highest phenolic content is in the seed (3602 mg GAE/ $100 \mathrm{~g}$ of seed DB).

Açaí pulp was reported with high phenolic content (3268 $3437 \mathrm{mg} \mathrm{GAE} / 100 \mathrm{~g}$ pulp DB) [23, 27]. Most of the research about açaí is centered on the pulp, which consists of the whole edible part (pulp and peel - mesocarp) added of water and, in many cases, bought in markets without information about the origin. Against this difficult to compare the results of this work with the literature, the value of TP of $1452 \pm 23$ $\mathrm{mg} \mathrm{GAE} / 100 \mathrm{~g}$ (DB) of pulp and peel fraction was lower than those report by the authors.

Comparing the values obtained on dry basis, the peel and pulp fractions have high antioxidant capacity (45.8 and 48.2 $\mu \mathrm{mol} \mathrm{TE} / \mathrm{g}$, respectively - Table 4), whereas the seed fraction has the highest value $(\sim 88.5 \mu \mathrm{mol} \mathrm{TE} / \mathrm{g})$ with contribution of the high phenolic content. However, the antioxidant capacity of the peel plus pulp presented the value of $11.96 \pm 0.13$ $\mu \mathrm{mol} \mathrm{TE} / \mathrm{g}$.

The results of the antioxidant activity demonstrated in the present study are higher than those reported by Gordon et al. [27], who found $2.78 \pm 0.10 \mu \mathrm{mol} \mathrm{TE} / \mathrm{g}$ (DB) for açaí pulp. According to these authors, the antioxidant activity was increased with the ripening of the fruit. 
Table 4. Total phenolic compounds, total anthocyanins and antioxidant capacity of açaí fruit fractions

\begin{tabular}{|c|c|c|c|c|c|c|c|c|c|c|}
\hline \multirow{2}{*}{ Analyses } & \multicolumn{2}{|c|}{ Whole Fruit ${ }^{1}$} & \multicolumn{2}{|c|}{ Pulp Plus Peel } & \multicolumn{2}{|c|}{ Peel } & \multicolumn{2}{|c|}{ Pulp } & \multicolumn{2}{|c|}{ Seed } \\
\hline & $\mathrm{WB}^{2}$ & $\mathrm{DB}^{3}$ & WB & DB & WB & DB & WB & DB & WB & DB \\
\hline $\begin{array}{c}\text { Phenolic } \\
\text { compounds }^{4} \\
(\mathrm{mg} \mathrm{GAE} / 100 \mathrm{~g})\end{array}$ & $\begin{array}{c}1386 \pm \\
104\end{array}$ & $\begin{array}{c}2370 \pm \\
177\end{array}$ & $912 \pm 14$ & $1452 \pm 23$ & $333 \pm 19$ & $\begin{array}{c}2584 \pm \\
145\end{array}$ & $117 \pm 10$ & $2123 \pm 179$ & $\begin{array}{c}2004 \pm \\
49\end{array}$ & $\begin{array}{c}3602 \pm \\
88\end{array}$ \\
\hline $\begin{array}{c}\text { Total } \\
\text { Anthocyanins } \\
\left(\mathrm{mg} .100 \mathrm{~g}^{-1}\right)\end{array}$ & $\begin{array}{c}47.73 \pm \\
7.54\end{array}$ & $\begin{array}{c}81.62 \pm \\
12.89\end{array}$ & $\begin{array}{c}120.19 \pm \\
1.07\end{array}$ & $\begin{array}{c}191.29 \pm \\
1.70\end{array}$ & $\begin{array}{c}48.09 \pm \\
0.95\end{array}$ & $\begin{array}{c}372.81 \pm \\
7.36\end{array}$ & $\begin{array}{c}11.10 \pm \\
2.85\end{array}$ & $\begin{array}{c}202.15 \pm \\
51.84\end{array}$ & - & - \\
\hline $\begin{array}{c}\text { Antioxidant } \\
\text { capacity } \\
(\mu \mathrm{mol} \mathrm{TE} / \mathrm{g})^{6}\end{array}$ & $\begin{array}{c}37.68 \pm \\
1.95\end{array}$ & $\begin{array}{c}64.44 \pm \\
3.33\end{array}$ & $\begin{array}{c}7.52 \pm \\
0.08\end{array}$ & $\begin{array}{c}11.96 \pm \\
0.13\end{array}$ & $\begin{array}{c}5.90 \pm \\
0.24\end{array}$ & $\begin{array}{c}45.81 \pm \\
1.87\end{array}$ & $\begin{array}{c}2.64 \pm \\
1.05\end{array}$ & $\begin{array}{c}48.18 \pm \\
19.07\end{array}$ & $\begin{array}{c}49.22 \pm \\
1.44\end{array}$ & $\begin{array}{c}88.46 \pm \\
2.60\end{array}$ \\
\hline
\end{tabular}

Values expressed as mean content \pm standard error.

${ }^{1}$ Whole fruit with seed; ${ }^{2} \mathrm{WB}=$ Wet weight basis; ${ }^{3} \mathrm{DB}=$ Dry weight basis; ${ }^{4}$ Expressed as gallic acid equivalent (GAE); ${ }^{5}$ Expressed as cyanidin 3 -glucoside $\left(E_{1 \mathrm{~cm}, 535 \mathrm{~nm}}^{1 \%}=98.2\right) .{ }^{6}$ Expressed as $\mu \mathrm{mol}$ Trolox Equivalent (TE) per $\mathrm{g}$ of sample

The comparison of the results of the antioxidant activity with the literature is difficult because different methods of analysis are used, and in addition values are often presented in wet form. Del Pozo-Insfran et al. [24] describe the açaí pulp as having a relatively high antioxidant content ( 48.6 $\mu$ mol Trolox equivalents $/ \mathrm{mL}$ ) with respect to other anthocyanin-rich fruits such as blueberries (4.6-31.1 $\mu \mathrm{mol}$ $\mathrm{TE} / \mathrm{g})$, strawberries (18.3-22.9 $\mu \mathrm{mol} \mathrm{TE} / \mathrm{g})$, raspberries (19.2-22.6 $\mu \mathrm{mol} \mathrm{TE} / \mathrm{g})$, blackberries (13.7-25.1 $\mu \mathrm{mol} \mathrm{TE} / \mathrm{g})$, cranberries $(8.20-145 \mu \mathrm{mol} \mathrm{TE} / \mathrm{g})$, and muscadine grape juice (18.2-26.7 $\mu \mathrm{mol} \mathrm{TE/g).} \mathrm{Pacho-Palencia} \mathrm{et} \mathrm{al.} \mathrm{[28]}$ found the value of antioxidant capacity of $61.5 \pm 1.21 \mu \mathrm{mol}$ Trolox equivalent $/ \mathrm{mL}$ of açaí pulp and Rufino et al. [26] found $64.5 \pm 19.3 \mu \mathrm{mol}$ Trolox/g (DB); these values are higher than that presented in this study.

It was clear that all parts of the açaí are rich in nutraceuticals, particularly phenolic compounds, which benefits are already recognized, such as its excellent oxidant scavenging capacity against peroxyl radicals and peroxynitrite, capability to attenuate chemically-induced colon carcinogenesis by increasing total hepatic total glutathione and attenuating DNA damage and preneoplastic lesion development, and exhibit the hypocholesterolemic effect by reducing total and non-high-density lipoprotein cholesterol, and superoxide dismutase activity [4, 8, 29].

Food Industry can uses different parts of the açaí for several purposes: for application in edible and biodegradable films to antioxidant and antimicrobial enrichment, such as chitosan film used in food packaging to improve oxidative stability of foodstuffs [30]. Peel provides a purple dye and can be use in functional low-fat beverage, considering that lipids are concentrate in the pulp. Since açaí pulp has high concentration of lipids, consumers prefer juices having low açaí content [6]. Pulp can be applied in ice cream because of its functionalities such as antioxidant, thickening and emulsifying, which are capable of improving texture.

\section{Conclusions}

Açaí is a good source of anthocyanins and phenolic compounds and the distribution of these compounds in fractions obtained from the açaí fruit was demonstrated for the first time. The richness of the açai fruit, original from Amazon, lies in its high antioxidant activity when compared to other anthocyanin-rich fruits. High content of anthocyanin was found in the peel fraction, whereas the majority of the phenolic content is distributed between peel and pulp. The seed normally discarded after processing showed high dietary fiber content and high phenolic content, consequently high antioxidant capacity. These results may allow the application of açaí fractions in the industry as functional food, promoter of better human health, and would have as advantage, with respect to the açaí traditional products, the high dietary fiber content and low caloric value, since no higher lipid content was observed in the peel fraction. This research allows the manufacture of new açaí products, taking into account the properties of the fractions studied here. The chemical characterization of the parts of the fruit allows elaborations of products with enhanced antioxidant properties.

\section{Acknowledgements}

The authors thank the AÇAÍMAZON Pesquisa, Indústria e Comércio de Açai Ltda, which supported the project and material provided, and $\mathrm{CNPq}$ for the research scholarship and FAPESP (proc. $n$ 2012/50374-1) for the financial support.

\section{REFERENCES}

[1] IBGE. (2012). Instituto Brasileiro de Geografia e Estatística. Online available from $<$ http:// www.ibge.gov.br>

[2] J. D. C. Pessoa, P. V. Silva. Effect of temperature and storage on açaí (Euterpe oleracea) fruit water uptake : simulation of 
fruit transportation and pre-processing. Fruits, Vol. 62, No 5, 295-301, 2007.

[3] D. R. Pompeu, E. M. Silva, H. Rogez. Optimisation of the solvent extraction of phenolic antioxidants from fruits of Euterpe oleracea using Response Surface Methodology. Bioresource Technology, Vol 100, No 23, 6076-82, 2009.

[4] R. Lichtenthäler, R. B. Rodrigues, J. G. S., Maia, M. Papagiannopoulos, H. Fabricius, F. Marx. Total oxidant scavenging capacities of Euterpe oleracea Mart. (Açaí) fruits. International Journal of Food Sciences and Nutrition, Vol 56, No 1, 53-64, 2005.

[5] L. A. Pacheco-Palencia, P. Hawken, S. T. Talcott. Phytochemical, antioxidant and pigment stability of açai (Euterpe oleracea Mart.) as affected by clarification, ascorbic acid fortification and storage. Food Research International, Vol 40, No 5, 620-628, 2007.

[6] S. Sabbe, W. Verbeke, R. Deliza, V. M. Matta,P. Van Damme. Consumer liking of fruit juices with different açaí (Euterpe oleracea Mart.) concentrations. Journal of Food Science, Vol 74, No 5, S171-6, 2009.

[7] S. U. Mertens-Talcott, J. Rios, P. Jilma-Stohlawetz, L. A. Pacheco-Palencia, B. Meibohm, S. T. Talcott, H. Derendorf. Pharmacokinetics of anthocyanins and antioxidant effects after the consumption of anthocyanin-rich acai juice and pulp (Euterpe oleracea Mart.) in human healthy volunteers. Journal of Agricultural and Food Chemistry, Vol 56, No17, 7796-802, 2008

[8] M. O. Souza, M. Silva, M.E. Silva, R. D. P.Oliveira, M. L. Pedrosa. Diet supplementation with acai (Euterpe oleracea Mart.) pulp improves biomarkers of oxidative stress and the serum lipid profile in rats. Nutrition (Burbank, Los Angeles County, Calif.), Vol 26, No 7-8, 804-10, 2010.

[9] D. Del Pozo-Insfran, S. S. Percival, S. T. Talcott. Açai (Euterpe oleracea Mart.) polyphenolics in their glycoside and aglycone forms induce apoptosis of HL-60 leukemia cells. Journal of Agricultural and Food Chemistry, Vol 54, No 4, 1222-9, 2006.

[10] S. Sabbe, W. Verbeke, R. Deliza, V. Matta, P. Van Damme. Effect of a health claim and personal characteristics on consumer acceptance of fruit juices with different concentrations of açaí (Euterpe oleracea Mart.). Appetite, Vol 53, No 1, 84-92, 2009.

[11] D. J. C. Pessoa, M. Arduin, M. A. Martins, J. E. Urano. Characterization of Açaí (E. oleracea) Fruits and its Processing Residues. Brazilian Archives of Biology and Technology, Vol 53, No December, 1451-1460, 2010.

[12] W. Horwitz, G. W. Latimer (Eds.). Official Methods os Analysis of AOAC International. In AOAC International (19th ed.). Arlington, VA: AOAC International, 2012.

[13] E. G. Bligh, W. J. Dyer. A rapid method of total lipid extraction and purification. Canadian Journal of Biochemistry and Physiology, 37(8), 911-917, 1959.

[14] L. Hartman, R. C. Lago. Rapid preparation of fatty acid methyl esters from lipids. Laboratory Practice, Vol 22, No 6, 475-6 passim, 1973.

[15] V. L. Singleton, J. A. Rossi. Colorimetry of Total Phenolics with Phosphomolybdic-Phosphotungstic Acid Reagents. American Journal of Enology and Viticulture, Vol 16, No 3,
144-158, 1965.

[16] F. J. Francis. Analysis of Anthocyanins. In P. Markakis (Ed.), Anthocyanins as Food Colors 181-207, 1982.

[17] T. Fuleki, F. J. Francis. Quantitative Methods for Anthocyanins. 1. Extraction and Determination of Total Anthocyanin in Cranberries. Journal of Food Science, Vol 33, No 1, 72-77, 1968.

[18] C. Zapsalis, F. J. Francis, F. J. Cranberry Anthocyanins. Journal of Food Science, Vol 30, No 3, 369-399, 1965.

[19] R. Re, N. Pellegrini, A. Proteggente, A. Pannala, M. Yang, C. Rice-Evans, C.Antioxidant activity applying an improved ABTS radical cation decolorization assay. Free Radical Biology and Medicine, Vol 26, No 9-10, 1231-1237, 1999.

[20] G. S. C. Borges, F. G. K. Vieira, C. Copetti, L. Valdemiro Gonzaga, R. C. Zambiazi, J. F. Mancini, R. Fett. Chemical characterization, bioactive compounds, and antioxidant capacity of jussara (Euterpe edulis) fruit from the Atlantic Forest in southern Brazil. Food Research International, Vol 44, No 7, 2128-2133, 2011.

[21] R. V. Tonon, C. Brabet, M. D. Hubinger. Anthocyanin stability and antioxidant activity of spray-dried açai (Euterpe oleracea Mart.) juice produced with different carrier agents. Food Research International, Vol 43, No 3, 907-914, 2010.

[22] S. Neida, S. Elba. Caracterización del acai o manaca (Euterpe olerácea Mart.): un fruto del Amazonas. Archivos LatinoAmericanos de Nutricion, Vol 57, No 1, 94-98, 2007.

[23] M. D. S. M. Rufino, J. Pérez-Jiménez, S. Arranz,R. E. Alves,E. S. de Brito, M. S. P. Oliveira,F. Saura-Calixto. Açaí (Euterpe oleraceae) "BRS Pará": A tropical fruit source of antioxidant dietary fiber and high antioxidant capacity oil. Food Research International, Vol 44, No 7, 2100-2106, 2011.

[24] D. Del Pozo-Insfran, C. H. Brenes, S. T. Talcott. Phytochemical composition and pigment stability of Açai (Euterpe oleracea Mart.). Journal of Agricultural and Food Chemistry, Vol 52, No 6, 1539-45, 2004.

[25] A. L. S. Dias, E. Rozet, G. Chataigné, A. C. Oliveira, C. A. S. Rabelo, P. Hubert, ... J. Quetin-Leclercq. A rapid validated UHPLC-PDA method for anthocyanins quantification from Euterpe oleracea fruits. Journal of Chromatography. B, Analytical Technologies in the Biomedical and Life Sciences, Vol 907, 108-16, 2012.

[26] M. D. S. M. Rufino, R. E. Alves,E. S. de Brito,J. Pérez-Jiménez, F. Saura-Calixto, J. Mancini-Filho. Bioactive compounds and antioxidant capacities of 18 non-traditional tropical fruits from Brazil. Food Chemistry, Vol 121, No 4, 996-1002, 2010.

[27] A. Gordon, A. P. G. Cruz, L. M. C. Cabral, S. C. de Freitas, C. M. A. D.Taxi, C. M. Donangelo, ... F. Marx. Chemical characterization and evaluation of antioxidant properties of Açaí fruits (Euterpe oleraceae Mart.) during ripening. Food Chemistry, Vol 133, No 2, 256-263, 2012. doi:10.1016/j.foodchem.2011.11.150

[28] L. Pacheco-Palencia, P. Hawken, S. Talcott. Juice matrix composition and ascorbic acid fortification effects on the phytochemical, antioxidant and pigment stability of açai (Euterpe oleracea Mart.). Food Chemistry, Vol 105, No 1, 28-35, 2007. 
[29] G. R. Romualdo, M. F. Fragoso, R. G. Borguini, M. C. P. A. Santiago, A. A. H. Fernandes, L. F. Barbisan. Protective effects of spray-dried açai (Euterpe oleracea Mart.) fruit pulp against initiation step of colon carcinogenesis. Food Research International, Vol 77, Part 3, 432-440, 2015.
[30] E. Genskowsky, L. A. Puente, J. A. Pérez-Álvarez, J. Fernandez-Lopez, L. A. Muñoz, M. Viuda-Martos. Assessment of antibacterial and antioxidant properties of chitosan edible films incorporated with maqui berry (Aristotelia chilensis). LWT - Food Science and Technology, Vol 64, N. 2, 1057-1062, 2015. 